\title{
PENGARUH PMRI BERBANTUAN “KNOW-WHAT-LEARN WORKSHEET” TERHADAP SIKAP KEMAMPUAN PEMECAHAN MATEMATIKA
}

\author{
I Nym Bagus Pramartha ${ }^{1 \S}$, Deviana ${ }^{2}$ \\ ${ }^{1}$ ITB STIKOM Bali [Email: baguspramartha@yahoo.co.id] \\ ${ }^{2}$ ITB STIKOM Bali [Email: devianamath@gmail.com] \\ ${ }^{\S}$ Corresponding Author
}

\begin{abstract}
Mathematics is a critical tool for young people as they confront issues and challenges in personal, occupational, societal, and scientific aspects of their lives. It is thus important to have an understanding of the degree to which young people emerging from school are adequately prepared to apply mathematics to understanding important issues and solving meaningful problems. This study aims to know the effect of Indonesian realistic mathematics education learning (PMRI) using knowwhat-learn worksheet to students' attitude and problem solving ability of grade VII SMP Negeri 1 Kuta Utara. This research is a combination research that used concurrent embedded design mixed methods. The population of the research was the students of grade VII of SMP Negeri 1 Kuta Utara in 2016/2017. Two classes as samples were taken from twelve classes with cluster random sampling technique. Data were analyzed using MANOVA. The results of the study shows that (1) PMRI using Know-What-Learn Worksheet Learning positively affected the students' attitude and math problem solving ability $(\lambda=25.440, p>0.05)$, (2) PMRI using Know-What-Learn Worksheet learning process can improve interest in math, understanding, liveliness in the learning process, and math meaningfulness in the daily life of students.
\end{abstract}

Keywords: PMRI, Worksheet, Attitude, Ability.

\section{PENDAHULUAN}

Matematika tumbuh dan berkembang karena proses berpikir, oleh karena itu logika adalah dasar untuk terbentuknya matematika. Belajar matematika itu sendiri merupakan proses psikologis berupa kegiatan aktif dalam upaya seseorang untuk memahami atau menguasai materi matematika. Berdasarkan Permendikbud (2014), pembelajaran matematika bertujuan agar peserta didik memiliki kemampuan dalam: memahami konsep matematika, menjelaskan keterkaitan antar konsep dan mengaplikasikan konsep atau algoritma, secara luwes, akurat, efisien dan tepat dalam pemecahan masalah.

Sebagai langkah lanjutan dari penetapan hal tersebut, National Council of Teachers of Mathematics (2000), merekomendasikan kurikulum matematika harus memberikan tempat bagi pengembangan kompetensi matematis pelajar dalam pemecahan masalah agar pelajar dapat menggunakan pemecahan masalah untuk menginvestigasi dan memahami konsep matematika secara mendalam; mengembangkan dan mengaplikasikan berbagai strategi pemecahan masalah matematika secara kritis dan kreatif, dengan penekanan pada prinsip multistrategi dan multilangkah, serta masalah-masalah nonrutin; memverifikasi dan menginterpretasi hasil pemecahan masalah sesuai dengan situasi masalah matematika orisinal; menggeneralisasikan pemecahan dan solusi serta strategi pada situasi masalah matematika yang baru, serta; membangun rasa percaya diri dalam menggunakan matematika secara bermakna dalam situasi kehidupan yang relevan. 
Akan tetapi pada praktek pembelajaran yang menggunakan masalah, ternyata masih menemui banyak kendala terkait dengan ketidakmampuan pelajar dalam memecahkan masalah matematika. Menurut Sudiarta (2007) melalui rekaman trajektori pembelajaran matematika yang berorientasi pemecahan masalah menemukan bahwa praktek pembelajaran berorientasi pemecahan masalah masih menemui banyak kendala, yang terutama disebabkan oleh faktor-faktor berikut: a) kelemahan didaktis, yaitu bagaimana guru merencanakan masalah matematika yang bisa diubah menjadi sarana untuk memacu peningkatan kompetensi tingkat tinggi pelajar yang meliputi kompetensi berpikir dan berlaku kritis dalam menganalisis, mensintesis, dan mengevaluasi; b) kelemahan pedagogis, yaitu bagaimana guru berperan sebagai fasilitator, mengambil keputusan, dan scaffolding yang akurat serta membagikan motivasi agar terjadinya interaksi mental antar pelajar; c) kelemahan dalam membantu struktur kognitif pelajar terutama yang berhubungan dengan intelek, yakni bagaimana konsep-konsep matematika sebelumnya dibentuk, dikonstruksi dan direkonstruksi, dipraktikkan, dan digambarkan secara mendalam.

Dalam penelitian ini peneliti akan menggunakan pendekatan Pendidikan Matematika Realistik Indonesia (PMRI) yang lebih mengarahkan pelajar pada masalah matematika yang realistik yang berarti mudah untuk dibayangkan oleh pelajar. Penggunaan masalah yang diberikan digunakan untuk membangun pemahaman pelajar pada konsep yang dibelajarkan dan meningkatkan kemampuan pemecahan masalah pelajar pada materi terkait serta dapat mengkonstruksi sendiri pengetahuan yang baru dengan mengaitkan pengetahuan awal mereka untuk mendapatkan pengetahuan yang baru.

Dalam pembelajaran dengan pendekatan PMRI pengetahuan awal pelajar cukup mempengaruhi pembentukan pengetahuan yang baru, tetapi dalam PMRI pengetahuan awal hanya dilakukan secara lisan dan bersamaan dengan pelajar lainnya. Maka dari itu, untuk memaksimalkan pembelajaran dikelas, peneliti menyisipkan Know-What-Learn Worksheet ( $K$ $W$ - $L$ Worksheet) dalam proses pembelajaran. $K$ -
W-L Worksheet ini diharapkan dapat lebih meningkatkan keaktifan dan kejelasan pada pengetahuan awal pada masing-masing pelajar karena pada pembelajaran ini $K$ - $W$ - $L$ Worksheet diberikan kepada masing-masing pelajar. Pemberian $K$-W-L Worksheet ini merupakan pengetahuan awal yang dapat disampaikan secara tulisan dan dilakukan oleh masingmasing pelajar dimana pelajar menuliskan apa yang mereka ketahui, apa yang mereka ingin tahu, dan apa yang mereka telah pelajari pada lembar kerja. Selain pelajar mencari tahu permasalahan yang diajukan dari guru, pelajar akan mencoba membantu dan mencari jalan keluar atas jawaban dari pertanyaan-pertanyaan yang diajukan oleh teman-temannya dan juga dapat membantu pelajar dalam mengaitkan pengetahuan awal mereka untuk mengkonstruksi pengetahuan yang baru melalui masalah matematika yang diberikan. Pembelajaran ini diharapkan dapat meningkatkan keaktifan seluruh pelajar dalam kegiatan pembelajaran dan juga memberitahu pelajar betapa pentingnya pengetahuan awal karena akan sangat membantu untuk pembelajaran materi berikutnya. Disamping itu, $K-W$ - $L$ Worksheet diberikan agar pelajar terbiasa mengerjakan masalah matematika dengan sistematis, rapi, dan terbiasa merangkum inti pembelajaran pada setiap pertemuan yang dapat dijadikan sebagai bahan review pada pertemuan selanjutnya.

Tujuan yang ingin dicapai adalah mengetahui pengaruh pembelajaran PMRI Berbantuan $K-W-L$ Worksheet terhadap sikap dan kemampuan pemecahan masalah matematika pelajar dan bagaimana pembelajaran PMRI berbantuan " $K-W-L$ Worksheet" mempengaruhi sikap dan kemampuan pemecahan masalah matematika pelajar.

\section{METODE PENELITIAN}

Penelitian ini merupakan penelitian dengan metode campuran (mixed methods) dan sebagai suatu langkah penelitian dengan menggabungkan dua bentuk penelitian yang sudah dilakukan sebelumnya yakni penelitian kualitatif dan kuantitatif. 


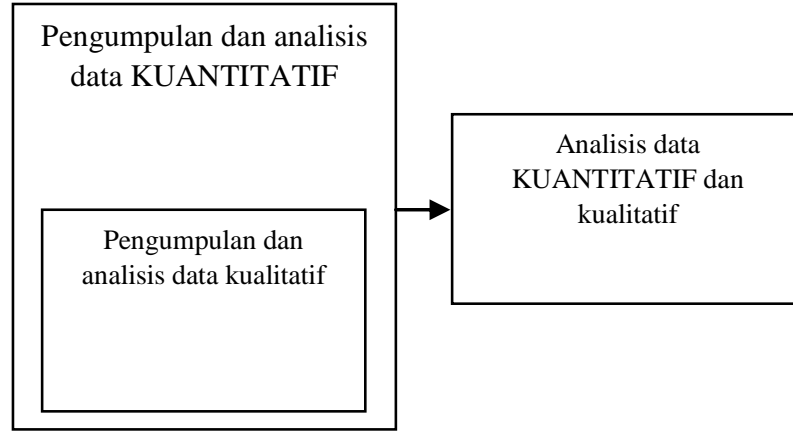

Gambar 1. Mixed Methods (Concurrent Embedded) dengan Model Metode Kuantitatif (Sugiyono, 2011).

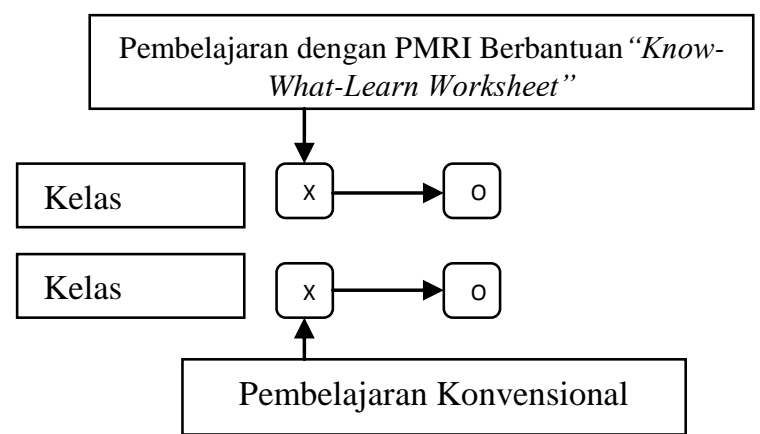

Gambar 2. Rancangan The Randomized Posttest Only Control Group Design (Yusuf, 2014)

Tabel 1. Hasil Statistik Deskriptif

\begin{tabular}{|l|l|l|l|l|}
\hline $\begin{array}{r}\text { Model } \\
\text { Pembelajaran } \\
\text { Statistik }\end{array}$ & $\mathrm{A}_{1} \mathrm{Y}_{1}$ & $\mathrm{~A}_{2} \mathrm{Y}_{1}$ & $\mathrm{~A}_{1} \mathrm{Y}_{2}$ & $\mathrm{~A}_{2} \mathrm{Y}_{2}$ \\
\hline $\mathrm{N}$ & 33 & 34 & 33 & 34 \\
\hline Mean & 40.3939 & 59.06 & 66.6364 & 70.6765 \\
\hline Median & 40 & 56 & 67 & 72 \\
\hline $\begin{array}{l}\text { Standar } \\
\text { deviasi }\end{array}$ & 9.38 & 12.47 & 7.411 & 8.94 \\
\hline Varians & 87.93 & 155.57 & 52.195 & 79.922 \\
\hline Rentangan & 37 & 41 & 32 & 37 \\
\hline Maksimum & 60 & 81 & 80 & 86 \\
\hline Minimum & 23 & 40 & 48 & 49 \\
\hline
\end{tabular}

Populasi dalam penelitian ini adalah seluruh pelajar kelas VII semester I tahun pelajaran 2016/2017 yang terdiri dari12 kelas yaitu kelas VII A, VII B, VII C, VII D, VII E, VII F, VII G, VII H, VII I, VII J, VII K, VII L yang terdistribusi di dalam kelas-kelas homogen secara akademik.

Pengambilan sampel dalam penelitian ini dilakukan dengan teknik cluster random sampling sebagai metode primer dan metode kualitatis sebagai metode sekunder sehingga diperoleh kelas B dan kelas C sebagai sampel. Untuk sampel data kualitatif hanya akan dipilih 3 orang pelajar secara acak dalam kelas eksperimen yang mengikuti pembelajaran dengan penerapan PMRI berbantuan " $K-W-L$ Worksheet" guna mengetahui bagaiman apenerapan Pendidikan Matematika Realistik Indonesia berbantuan " $K-W-L$ Worksheet" mempengaruhi sikap dan kemampuan pemecahan masalah pelajar pada materi segiempat dan segitiga.

\section{HASIL DAN PEMBAHASAN}

Menurut hasil analisis terhadap sikap dan pemecahan masalah matematika pelajar, diketahui bahwa rata-rata sikap pelajar pada kelompok kontrol adalah 66.63dan rata-rata sikap pelajar pada kelompok eksperimen adalah 70.67 serta rata-rata pemecahan masalah matematika pelajar pada kelas kontrol adalah 40.39 dan rata-rata pemecahan masalah matematika pelajar pada kelas eksperimen adalah 59.06, dilihat dari hasil tersebut terlihat bahwa rata-rata pada kelompok kelas eksperimen lebih tinggi dibandingkan dengan kelompok kelas kontrol pada sikap maupun kemampuan pemecahan masalah matematika pelajar.

Dari hasil angket sikap pelajar pada kelompok eksperimenter dapat pelajar yang memberikan respon sangat setuju dalam pernyataan positif yang menyatakan bahwa matematika memberikan tuntunan untuk berpikir logis dan rasional. Pada kelompok kontrol juga memberikan respon setuju untuk pernyataan yang sama. Sedangkan pada pernyataan negatif, respon pelajar baik itu kelompok eksperimen maupun kelompok kontrol sama-sama memberikan respon tidak setuju terhadap pernyataan yang diberikan. Akan tetapi terdapat suatu perbedaan hasil 
respon pelajar yang menarik bagi peneliti yaitu pada nomor 10 dan 19. Untuk pernyataan nomor 10, pada kelompok eksperimen 16 anak menyatakan sangat setuju pada pernyataan positif yang menyatakan bahwa pembelajaran dikelas bagi saya sangat menyenangkan, sementara dikelas kontrol menyatakan hanya terdapat 6 anak yang menyatakan sangat setuju. Hal ini terjadi karena pembelajaran dikelas eksperimen memacu cara berpikir kreatif pelajar dalam memecahkan masalah matematika dan juga keaktifan pelajar, pembelajaran dilakukan dengan serius tetapi santai sehingga pembelaran berlangsung dengan menyenangkan. Untuk pernyataan nomor 19, pada kelompok eksperimen mayoritas anak menyatakan setuju untuk pernyataan positif yaitu saya membuat ringkasan matematika dengan bahasa sendiri, sedangkan pada kelompok kontrol mayoritas anak menyatakan ragu untuk pernyataan yang sama. Hal ini disebabkan karena dalam pembelajaran dengan penerapan PMRI berbantuan $K-W-L$ Worksheet pelajar sudah terbiasa membuat ringkasan tentang materi yang dipelajari dengan bahasanya sendiri, karena pada saat memecahkan masalah semua kegiatan yang berhubungan dengan materi dalam hal ini cara memecahkan masalah matematika akan segera ditulis oleh pelajar pada $K-W$ - $L$ Worksheet ini mengakibatkan pelajar dapat dengan mudah melihat atau mempelajari kembali materi sebelumnya pada $K$-W-L Worksheet.

Dari lembar pemecahan masalah dapat dilihat bahwa cara pelajar memecahkan masalah sudah cukup terstruktur. Salah satu kendala dalam pembelajaran adalah pelajar tidak terbiasa mengerjakan masalah secara sistematis. Untuk mengatasi kendala tersebut, dalam pembelajaran di kelas eksperimen pelajar dibiasakan bekerja dalam lembar pemecahan masalah yang menuntun pelajar untuk menuliskan informasi yang diberikan dalam soal, menuliskan rencana penyelesaian, kemudian sampai pada melaksanakan penyelesaian.Hasil analisis terhadap lembar pemecahan masalah tes pemecahan masalah pelajar yang mengikuti pembelajarandengan strategi pembelajaran konvensional, banyak pelajar yang gagal dalam menuliskan informasi yang diberikan dalam soal. Kegagalan ini membuat kegagalan beruntun pada ketidakmampuan pelajar dalam membuat perencanaan dan pada akhirnya pelajar tidak mampu memecahkan soal tersebut.

Pelajar yang mengikuti pembelajaran dengan pembelajaran dengan penerapan PMRI berbantuan $K-W-L$ Worksheet mempunyai semangat lebih dalam memecahkan masalah. Hal ini dibuktikan dengan hasil tes kemampuan pemecahan masalah pelajar dimana skor maksimum yang dicapai pada kelas eksperimen adalah 81 sementara pada kelas kontrol hanya mencapai 60, meskipun frekuensinya sedikit.

Pembelajaran dengan strategi pembelajaran dengan penerapan PMRI berbantuan $K-W-L$ Worksheet yang diterapkan membuat suasana pembelajaran menjadi menyenangkan dan nyaman. Hal ini merangsang pelajar menjadi lebih berani untuk mengemukakan pendapatnya, mengkomunikasikan penyelesaian dari permasalahan yang didapat, dan lebih berani untuk bertanya kepada guru terkait dengan hal-hal yang belum dimengerti.

Proses penyelesaian masalah dalam $K-W-L$ Worksheet dilakukan melalui diskusi kelompok, sehingga pembelajaran di kelas dapat melatih pelajar untuk demokratis serta mendorong setiap anggota kelompok untuk berperan aktif dalam mengajukan argumentasinya, memikirkan ide-ide penyelesaian, mencermati dan menghargai pendapat temannya, dan bertukar pikiran. Ketika pelajar berperan aktif saat mengerjakan $K$-W-L Worksheet tersebut, terjadi transformasi dan konstruksi pengetahuan. Berdasarkan teori konstruktivisme pelajar dituntut untuk lebih berinovasi dalam meningkatkan pengetahuan. Pelajar diharapkan mampu mencari, menggali, dan mengembangkan sendiri pengetahuannya sehingga pelajar lebih aktif terlibat dalam proses pembelajaran.

Secara umum, peningkatan yang terjadi pada kemampuan pemecahan masalah matematika pelajar sebenarnya juga disebabkan oleh tahapan-tahapan pembelajaran yang sudah disusun sedemikian rupa sehingga proses dapat berjalan lancar dan dapat mencapai tujuan pembelajaran yang diharapkan. Tahapantahapan pembelajaran yang ditetapkan tidak terlepas dari hakekat pembelajaran matematika yang menekankan agar pelajar senantiasa belajar dengan aktif dan tidak hanya bersikap menerima informasi dari guru. Pada pembelajaran yang dilaksanakan diawali dengan mengaitkan pembelajaran dengan permasalahan yang menyentuh dunia nyata pelajar, dengan memberikan motivasi kepada 
pelajar akan membangkitkan minat belajar pelajar sehingga pelajar merasakan manfaat dari belajar matematika dalam kehidupan sehari-hari, hal ini menyebabkan pelajar merasa lebih tertarik dan bergairah dalam mengikuti proses pembelajaran.

Dalam pembelajaran dengan penerapan PMRI, pelajar dibagi menjadi beberapa kelompok belajar yang heterogen untuk mendiskusikan lembar permasalahan yang diberikan guru. Melalui pembelajaran ini kekurangan pelajar dalam memecahkan masalah matematika dapat ditanggulangi karena pelajar dapat berdiskusi dengan teman dalam kelompoknya sehingga pelajar yang merasa kurang dalam pemecahan masalah akan lebih suka bertanya kepada temannya daripada dengan guru. Bersama dengan kelompoknya pelajar dengan bantuan $K-W-L$ Worksheet untuk mengalami sendiri dalam memecahkan permasalahan berdasarkan pengalaman dan cara berpikir yang dimilikinya. Adanya $K-W-L$ Worksheet yang diberikan kepada masingmasing pelajar diharapkan dapat menjadi pembelajaran menjadi lebih efektif karena setiap hal yang diperlukan dan berkaitan dengan masalah yang diberikan dicatat secara sistematis yang nantinya bisa mereka kaji sebagai bentuk pencapaian dalam mengikuti pembelajaran. Setiap teori yang mereka telah ketahui bisa mereka catat dan setiap pembelajaran baru yang mereka dapatkan juga mereka catat guna melengkapi dan memperdalam pemahaman materi yang mereka pelajari yang nantinya dijadikan pedoman dalam memecahkan permasalahan dalam kehidupan sehari-hari mereka.

Berdasarkan hasil observasi dan wawancara selama kegiatan penelitian dapat disampaikan beberapa hal sebagai berikut.

Pertama, pelajar terlebih dahulu diberikan permasalahan. Pelajar mulai mengamati masalah matematika, kemudian dalam proses penyelidikan, pelajar diberikan kesempatan untuk memecahkan permasalahan tersebut. Guru hanya sebagai fasilitator dengan memberikan pertanyaan arahan, sampai pelajar sendiri yang memecahkan dan mencari alternatif pemecahan lain. Pada fase inilah selanjutnya terjadi proses penemuan konsep ke arah yang lebih formal untuk memecahkan masalah tersebut. Dengan bimbingan guru, pelajar diarahkan untuk membentuk konsep dengan pemahaman mereka dan menarik suatu kesimpulan terhadap masalah tersebut.

Kedua, pelajar semakin aktif dikelas. Hal ini ditandai dengan antusiasnya pelajar dalam menjawab pertanyaan-pertanyaan yang dilontarkan guru. Dalam kegiatan tanya jawab atau penyelesaian soal ke depan kelas, sering kali pelajar tampak kecewa ketika mereka tidak mendapat kesempatan untuk menyajikan hasil diskusi ke depan kelas. Pada awalnya mereka malu bertanya tetapi peneliti memotivasi pelajar dan memberikan penghargaan bagi pelajar yang mau bertanya. Mereka akhirnya lebih percaya diri dan tidak malu untuk bertanya.

Pada dasarnya pembelajaran konvensional dan pembelajaran dengan penerapan PMRI berbantuan $K$-W-L Worksheet sama-sama baik untuk diterapkan pada proses pembelajaran, walaupun jika dibandingkan penerapan PMRI berbantuan $K$-W-L Worksheet menujukkan hasil sikap dan kemampuan pemecahan masalah matematika yang lebih baik dibandingkan dengan hasil sikap dan kemampuan pemecahan masalah matematika yang mengikuti penerapan pembelajaran konvensional. Hal tersebut berdasarkan hasil statistik deskriptif, dapat dilihat bahwa rata-rata sikap pelajar pada kelompok kontrol adalah 66.63dan rata-rata sikap pelajar pada kelompok eksperimen adalah 70.67, dengan kata lain, bahwa penerapan pembelajaran PMRI berbantuan $K-W-L$ Worksheet lebih unggul dibandingkan pembelajaran konvensional dalam pencapaian sikap. Untuk kemapuan pemecahan masalah matematika, dilihat dari statistik deskriptif ratarata pemecahan masalah matematika pelajar pada kelas kontrol adalah 40.39 dan rata-rata pemecahan masalah matematika pelajar pada kelas eksperimen adalah 59.06. Hal ini disebabkan karena keuntungan yang diberikan pada pembelajaran dengan PMRI berbantuan $K-W$-L Worksheet yang menjadikan masalah yang mudah dibayangkan oleh pelajar sebagai pemacu dalam cara berpikir pelajar untuk memecahkan masalah yang diberikan sehingga pelajar bisa mengkontruksi dan berpikir lebih kreatif lagi dalam pemecahan masalah matematika, situasi seperti ini menjadi faktor pendukung untuk mencapai efektivitas belajar sehingga menambah semangat dan rasa ingin tahu pelajar untuk memecahkan suatu masalah. Disamping itu $K-W-L$ Worksheet juga 
membantu pelajar dalam memecahkan masalah yang diberikan dengan melatih pelajar untuk mengerjakan masalah matematika dengan terstruktur dengan memperhatikan pengetahuan awal yang dimiliki pelajar.

Rumusan masalah yang kedua adalah bagaimana pembelajaran dengan PMRI berbantuan $K-W-L \quad$ Worksheet pada pembelajaran matematika dapat mempengaruhi sikap dan kemampuan pemecahan masalah pelajar. Berdasarkan hasil analisis kualitatif dapat diketahui bahwa pelajar yang mengikuti pembelajaran dengan penerapan PMRI Berbantuan $K-W-L \quad$ Worksheet, cenderung menunjukkan sikap ketertarikan, pemahaman, keaktifan, dan kebermaknaan matematika dalam kehidupan sehari-hari. Ini disebabkan karena aktifitas pelajar dalam pembelajaran dengan penerapan PMRI Berbantuan $K-W-L$ Worksheet menjadi lebih aktif, mereka dapat berinteraksi dengan sesama temannya, diskusi, negosiasi, dan kolaborasi.

\section{KESIMPULAN DAN SARAN}

Pembelajaran dengan penerapan PMRI berbantuan $K$-W-L Worksheet berdampak positif terhadap sikap dan kemampuan pemecahan masalah matematika pelajar. Ini ditunjukkan dengan lebih tingginya sikap dan kemampuan pemecahan masalah matematika pelajar yang mengikuti pembelajaran dengan penerapan PMRI berbantuan $K$ - $W$ - $L$ Worksheet dibandingkan kelompok pelajar yang mengikuti pembelajaran konvensional yang dilihat dari nilai rata-rata angket sikap pelajar dan tes kemampuan pemecahan masalah matematika pelajar.

Selama proses belajar PMRI berbantuan $K$ $W$ - $L$ Worksheet terdapat 5 tahap dalam proses pembelajarannya, tahap pertama yakni memahami kondisi dimana pada awal pembelajaran, guru mengusulkan masalah realistik kemudian pelajar diminta memecahkan masalah tersebut. Guru hendaknya menentukan masalah yang memiliki cara penyelesaian yang divergen dan juga menyampaikan peluang untuk menghasilkan berbagai strategi pemecahan masalah. Dalam memecahkan permasalahan realistik ini pelajar menyelesaikan dengan model sendiri sehingga konsep yang diterima pelajar akan lebih bermakna. Tahap kedua adalah memperhatikan atau menentukan strategi yang tepat untuk memecahkan masalah. Pada tahap ini guru meminta pelajar menjelaskan atau mendeskripsikan permasalahan yang diberikan dengan pemahaman mereka sendiri. Dari sini pelajar dilatih untuk bernalar dan memilih strategi yang tepat sehingga pelajar menjadi terlibat lebih aktif lagi dalam proses pembelajaran. Tahap ketiga yakni memecahkan masalah realistik. Pada tahap ini, pelajar secara individu atau kelompok memecahkan masalah yang diajukan guru. Pelajar diharapkan dapat mengkomunikasikan penyelesaian masalah atau berdiskusi dengan anggota kelompoknya. Tahap keempat yakni membandingkan dan mendiskusikan penyelesaian masalah. Pada tahap ini, dapat meningkatkan rasa berani pelajar dalam menyampaikan pendapat tentang hasil diskusi yang telah dilakukan kedepan kelas, pelajar menjadi lebih aktif dalam proses pembelajaran baik dalam mempresentasikan maupun memberikan tanggapan dari hasil diskusi. Tahap kelima yakni menegosiasi pemecahan masalah dimana guru mengarahkan pelajar untuk menarik kesimpulan tentang materi yang telah dipelajari. Dalam pembelajaran ini, penggunaan $K-W-L$ Worksheet yang diberikan ke masing-masing pelajar dapat meningkatkan keaktifan pelajar dan menghindari hanya 1 atau 2 orang berfikir. Disamping itu, pelajar akan terbiasa mengerjakan masalah matematika dengan sistematis, rapi, terbiasa untuk merangkum inti pembelajaran pada setiap pertemuan, dan $K$-W$L$ Worksheet dapat dijadikan bahan review pelajar pada pertemuan selanjutnya.

Dilihat dari proses pembelajarannya PMRI berbantuan $K-W$-L Worksheet mampu meningkatkan sikap ketertarikan, pemahaman, keaktifan, dan kebermaknaan matematika dalam kehidupan sehari-hari pelajar disebabkan karena pembelajaran ini sangat menarik.

\section{DAFTAR PUSTAKA}

NCTM. 2000.Principles and Standards for School Mathematics. United State of America: The National Council of Teachers of Mathematics, Inc..

Permendikbud. 2014."Peraturan Menteri Pendidikan dan Kebudayaan Republik Indonesia Nomor 59 Tahun 2014 Tentang Kurikulum 2013”. Jakarta: Departemen Pendidikan dan Kebudayaan.

Sudiarta. 2007."Pengembangan Pembelajaran Pendekatan Tematik Berorientasi 
Pemecahan Masalah Matematika Terbuka untuk Mengembangkan Kompetensi Berpikir Divergen, Kritis dan Kreatif". Jurnal Pendidikan dan Kebudayaan.
Sugiyono. 2011. "Metode Penelitian Kuantitatif, Kualitatif dan R\&D”. Bandung: Afabeta.

Yusuf. 2014. "Metodologi Penelitian Kuantiatif, Kualitatif \& Penelitian Gabungan”. Jakarta: Prenadamedia Group. 